\section{British schools fantasy}

The British government should not seek to make its second school-leaving examination even more exacting.

WILL the British educational system (outside Scotland) never be put on a rational basis? This summer, as always, pundits and people more generally have been brooding about the annual crop of results of the school-leaving examinations held earlier in the year. The results come in two forms, for there are two systems of school-leaving examinations. For 16-17 year-olds, there is a system called GCE, for "General Certificate of Education". Then there is a series of examinations for 18-19-year-olds, called A-levels, where "A" stands for "advanced". Why two? Because the A-level system has traditionally been aimed not at educational goals, but has been the means by which young people prepare themselves for university courses and also demonstrate their competence to benefit therefrom.

Now a strange thing has happened. Because the numbers of those gaining respectable qualifications at A-level have been rising and have further increased this year, there has been a groundswell of indignation that the examinations have become "easier", and that educational standards in British schools are falling. While an objective observer might conclude that an increase in the numbers of those qualifying as university entrants would be a sign of improving standards, the opposite opinion has paradoxically been strengthened by the discovery that some universities have been recruiting into "foundation courses" young people without A-level qualifications of any kind. Everything is going to the dogs seems to be the view, notably that of the London Times.

Mrs Gillian Shephard, an able minister who now looks after both education and employment, seems to have been caught up in the general panic. There is to be an enquiry, on which her department will spend $£ 100,000$, to tell whether educational standards are falling and to give new backbone to the A-level system. Sadly, the outcome cannot but entail more short-term administrative tinkering with a system that has long since outlived its usefulness and function. It will not lead to the more radical change in the pattern of secondary education, at the vital interface with higher education, that circumstances require.

The A-level system, once described by a former prime minister as the "jewel in the crown" of British education, has become an impediment to learning rather than a means by which young people in Britain (outside Scotland) can be prepared for adult life. To be sure, in the life of a secondary school, it is enlivening for many teachers and a proportion of the students that they should rehearse together curricula that really belong in higher education, but that requires a high price (in impoverished education) from those who will not end up in higher education. But even academically inclined young people are crippled by the system, being required to abandon general for specialized curricula too soon in their careers.
The rational reform of this bewildering set of circumstances has been plain for many years: require that secondary schools provide a general education for their students, including the cultivation of scholarship that will enable some of them to profit from further study at universities and elsewhere, but also emphatically require that secondary schools do not run a selection system for the universities and other higher education institutes. Over several years, there have been repeated attempts to loosen the present system, mostly by seeking to persuade universities to be less exacting in what they require as specialized knowledge from potential entrants, but with only little success. Yet in a climate in which universities and other institutes are being repeatedly told that their future hangs on the decisions on educational policy they make for themselves, is it not proper that they should by responsible for their choice of students?

It is especially sad that Mrs Shephard has apparently taken seriously the canard that some universities (mostly institutions recently graduated from the status of polytechnic) are offering foundation courses to students without qualifications at A-level. At worst, that is means of providing extra education to young people who manifestly both need and seek it. But such a pattern of higher education is also educationally desirable. It is also the pattern followed in most other countries in the world than Britain. Especially when Britain is constantly looking over its shoulder at the performance of its competitors elsewhere, why should it set its face against a pattern of education that appears excellently to have met the needs of, for example, Japan and the United States.

The British pattern is especially disadvantageous for the recruitment of young people into science. Opting for A-level studies of a kind likely to win a place at a university requires a decision to that effect at 16 or 17, and often denies a young person the chance to follow more general aspects of the curriculum on offer at his or her school. That is also an age at which young people take more than passing interest in the prospects that their studies will largely determine their careers, influencing both the chance that they will find a job and that it will reward them well. Yet that is precisely the age at which, to many young people in present circumstances, keeping options open seems the wisest strategy. So long as a career in science requires the almost monastic preparation now customary in Britain, the numbers of entrants to science courses in higher education will continue to dwindle.

Effecting change on this scale would not, of course, be simple. Universities would have to abandon the present practice that young people are mostly recruited not by the university but by its departments. Some teachers would have to teach more elementary classes. There would be a redistribution of costs between schools and higher education (but probably not as great as simple arithmetic suggests). Universities would find themselves standing where they belong, both in respect of accountability for their use of public funds and of academic freedom - on their own two feet. If Mrs Shephard wishes to make a mark with her enquiry, that is the direction she should explore. 